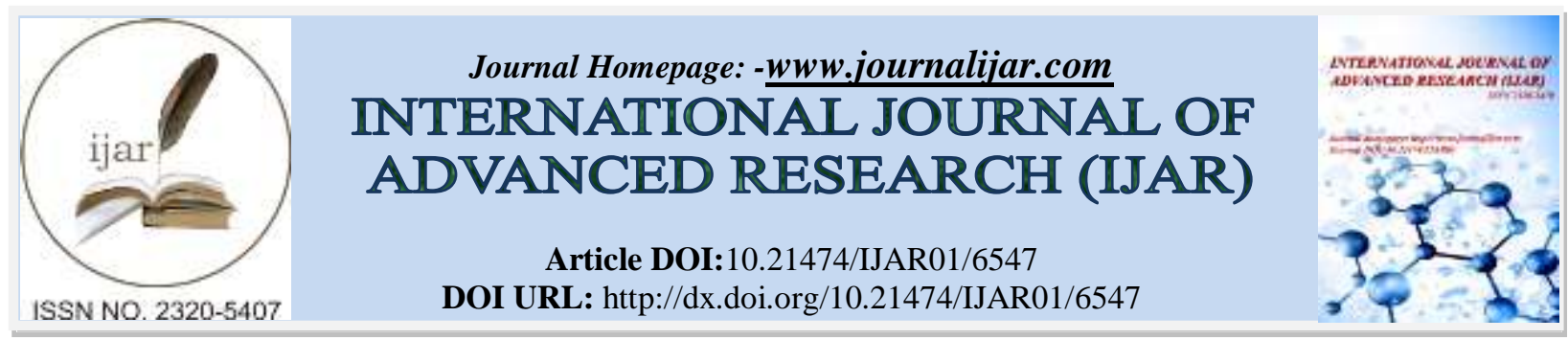

RESEARCH ARTICLE

\title{
COMBINING ABILITY AND HETEROSIS STUDIES IN SESAME (Sesamum indicum L.) GENOTYPES
}

\section{Myint Aye ${ }^{1}$, Soe Win ${ }^{2}$ and Nang Hseng Hom ${ }^{3}$.}

1. Assistant Lecturer, Department of Plant Breeding, Physiology and Ecology, Yezin Agricultural University, Yezin, Nay Pyi Taw, Myanmar.

2. Professor, Department of Plant Breeding, Physiology and Ecology, Yezin Agricultural University, Myanmar

3. Prorector, Yezin Agricultural University, Yezin, Nay Pyi Taw, Myanmar.

\section{Manuscript Info}

\section{Manuscript History}

Received: 16 December 2017

Final Accepted: 18 January 2018

Published: February 2018

Keywords:-

Combining ability, heterosis, diallel, micro-environment.

\begin{abstract}
Exploitation of heterosis in most crops is one of the methods to increase yield. Knowledge of heterosis together with combining ability analysis is frequently used to choose good combiners and promising hybrid combinations. Thus, the objectives of this study were to evaluate combining abilities and heterosis of $F_{1}$ and $F_{2}$ generations and association of yield and yield components. The experiments were conducted in Yezin Agricultural University during 2006-2008. Eight varieties were crossed in a diallel mating design (Method 2). The parental lines along with $F_{1}, F_{2}$ progenies and 4 checks were grown in two micro-environments in RCB design with two replications. The crosses $(\mathrm{Co}-1 \times$ India 7B), (Co-1 $\times$ Sinyadana 3$),($ Co-1 $\times$ Yethaekyaw), (Sinyadana $11 \times$ Co-1) and (Co-1 $\times$ VTS-2009) had better mean yield performances and showed high heterosis values for yield. Among these, the two combinations $(\mathrm{Co}-1 \times$ India $7 \mathrm{~B})$ and $(\mathrm{Co}-1 \times$ Sinyadana 3$)$ showed high SCA effects. Therefore, these two combinations could be selected to use in production of hybrids. The genotype Co-1 was identified as the best general combiner having maximum GCA effect for more than half of the observed traits. There was no difference in yield performance between the $F_{1}$ and $F_{2}$ generations of Co- $1 \times$ Yathaekyaw cross. This $F_{2}$ generation might be used in production of sesame to save the cost of $F_{1}$ hybrid seeds. In correlation study, yield was significantly and positively correlated with days to maturity, plant height, primary branches, secondary branches and capsules per plant. Therefore, these five characters were the main yield contributing traits in sesame production.
\end{abstract}

Copy Right, IJAR, 2018,. All rights reserved.

\section{Introduction:-}

Edible oilseeds rank second in importance among food crops after cereals. Oilseeds such as sesame, niger, castor and linseed receive little attention. Yet these neglected oilseeds are key crops for millions of small scale farming families in developing countries (Thangavelu 1992). Sesame is normally $90 \%$ autogamous. However the degree of outcrossing to the extent of 65\% (Brar and Ahuja 1979), availability of male sterility (Ramalingam et al. 1994) and easiness in outcrossing through a massive manual hybridization technique (Yadav and Mishra 1991) have caught the 
attention of breeders for studying the extent of heterosis in sesame and for developing commercial hybrids in sesame.

Sesame oil is very excellent for the health of human beings comparing to the palm oil. In Myanmar, the palm oil is imported every year because of the self-insufficiency of edible oil consumption. To overcome this problem, the superior sesame lines (or) varieties are urgently needed. The major constraints to low yield are poor yielding cultivars and vagaries weather. Hence, it is urgently required to widen the genetic base through the introduction and creation of genetic variability through different techniques. Exploitation of exotic and indigenous germplasm is an important method for significant improvement. Therefore, it is necessary to obtain basic genetic information with seed yield. Breeders often wish to improve several traits of sesame simultaneously. This can be accomplished by the different selection methods and hybridization.

Knowledge on combining ability helps in selection of appropriate parents for a hybridization program for evolving superior $F_{1}$ hybrids as well as elite segregants with high seed yield in the segregating generations (Kumar et al. 2005). Exploitation of heterosis in most crops is one of the methods to increase yield. Studies on heterosis together with combining ability and gene action on seed yield and other traits in advanced generation are very limited. Therefore, this study was carried out with the following objectives: (1) to evaluate the general combining ability (GCA) and specific combining ability (SCA) for yield and yield components in first and second generations, (2) to investigate the extent of heterosis of $F_{1}$ and $F_{2}$ generations, and (3) to study the association of yield and its component characters among the studied sesame genotypes.

\section{Materials and Methods:-}

The experiments were conducted in Department of Plant Breeding, Physiology and Ecology. All the possible crosses $\{\mathrm{n}(\mathrm{n}-1) / 2\}$ were made to obtain $\mathrm{F}_{1}$ hybrids excluding reciprocals through an $(8 \times 8)$ diallel fashion. Evaluation study was conducted from October 2006 to January 2008 (post-monsoon) at the upland field of Yezin Agricultural University, Nay Pyi Taw, Myanmar. The eight parental genotypes, four checks and their original sources were shown in Appendix 1. Two times of sowing dates (micro-environments) were established from October 2006 to January 2008 (post-monsoon). First time of sowing (micro-environment 1) experiment was conducted on 1 October 2006 and second time of sowing (micro-environment 2) experiment was conducted on 23 October 2007.

The 68 genotypes viz, the eight parents, $28 \mathrm{~F}_{1} \mathrm{~s}, 28 \mathrm{~F}_{2} \mathrm{~s}$ and 4 checks were raised in a randomized complete block $(\mathrm{RCB})$ design with two replications. Each $\mathrm{F}_{1}$ plot consisted of a single row, $3 \mathrm{~m}$ long adopting a spacing of $0.5 \times$ $0.15 \mathrm{~m}$. Each $\mathrm{F}_{2}$ plot consisted of 2 rows, $3 \mathrm{~m}$ long following of $0.5 \times 0.15 \mathrm{~m}$. Plots were over-planted and thinned at the 21 days old to a final stand of approximately 21 plants in each row. Cultural practices for sesame production were conducted as usual.

Days to maturity, plant height, primary branches per plant, secondary branches per plant, number of capsules per plant, capsule length and yield per plant were collected on five random plants in each of the $\mathrm{F}_{1} \mathrm{~s}$ and their parents, and 10 individual plants of the $\mathrm{F}_{2}$ populations.

The data were statistically analyzed for simple analysis of variances according to PLABSTAT (Plant Breeding Statistics), version 2N (UTz 1997). The genotypes which were significantly different for each character from the previous analysis were used for combining ability analysis. The average mean values of the significant characters from two micro-environments were used in the study. The combining ability estimates were determined according to Model I (fixed effect), Method II given by Griffing (1956). Correlation coefficient between yield and yield component characters were calculated by PLABSTAT program (UTz 1997). The relative heterosis (Walton 1971), heterobeltiosis (Allard 1956) and standard heterosis in $F_{1}$ and $F_{2}$ were calculated for yield performance by using the following equations. The standard heterosis was computed by using the best check. Correlation coefficients of yield and yield component characters were calculated.

\section{Results and Discussion:-}

\section{Analysis of variances for yield and yield component characters:-}

The mean squares obtained from the analysis of variance for yield and yield components are presented in Table 1 . When the micro-environments were subjected to the analysis of variances, the mean squares were highly significant for days to maturity, plant height, capsules per plant, capsule length and yield per plant at $1 \%$ level. Mulkey et al. 
(1987) reported that days to maturity, plant height and seed yield were significantly affected by planting dates. Shim et al. (2006) reported that plant height, days to maturity and capsules per plant were highly significant at $1 \%$ level according to sowing dates or the micro-environments and seed weight per plant at $5 \%$ level. The mean squares of parental genotypes $(\mathrm{P})$ were observed significant for all characters except secondary branches. For $\mathrm{F}_{1}$ genotypes, all the characters were significant. The mean squares of $F_{2}$ progenies were significant for all characters except total branches. For checks, all characters were significant except secondary branches and capsule length. When genotype by environment $(\mathrm{G} \times \mathrm{E})$ interactions all characters were significant except the secondary branches.

Gene expression is subjected to modification by environment. Therefore, genotypic expression of the phenotype is environmentally dependent (Kang 1998). Inconsistent genotypic responses to environmental factors are a function of genotype by environment $(\mathrm{G} \times \mathrm{E})$ interactions. Genotype $\times$ environment interaction has been identified as the failure of genotypes to achieve the same relative performance in different environments (Baker 1988). Since genotypes were probably sensitive to environment effects, GE interaction was significant for days to maturity, plant height, primary branches, secondary branches, capsule per plant, capsule length and yield per plant. This indicated that the ranking of genotypes changed under different micro- environments. But GE interaction was not significant for secondary branches. This indicated that genotypes produced similar branches under change of environment.

\section{Heterosis performance for yield per plant of $F_{1}$ and $F 2$ progenies:-}

The estimates of heterosis for yield per plant over the mid parent (relative heterosis) observed in the $F_{1} s$ are presented in Figure 1. Positive relative heterosis was observed in all $\mathrm{F}_{1}$ progenies except the three crosses $(1 \times 3)$, $(1 \times 4)$ and $(2 \times 3)$. The maximum positive relative heterosis value $(229.68 \%)$ was found in $(2 \times 5)$ combination. The best five heterotic crosses were $(2 \times 5),(2 \times 8),(5 \times 8),(7 \times 8)$ and $(5 \times 7)$ with the values of $(229.68 \%),(165.67 \%)$, $(141.06 \%),(134.19 \%)$ and $(123.06 \%)$ respectively.

Only 22 among $28 \mathrm{~F}_{1}$ progenies showed positive heterobeltiosis while 6 crosses exhibited negative heterosis. The combination $(2 \times 5)$ showed the highest positive heterobeltiosis $(125.95 \%)$. The cross $(2 \times 3)$ had the highest negative heterobeltiosis value of $(-20.06 \%)$. The cross combinations $(2 \times 5),(5 \times 8),(2 \times 8),(7 \times 8)$ and $(2 \times 6)$ were the best five crosses with the heterobeltiosis values of $(125.95 \%),(106.00 \%),(102.28 \%),(100.52 \%)$ and $(82.13 \%)$ respectively. When the $\mathrm{F}_{1} \mathrm{~s}$ compared with the best check variety (Hnanni 25/160), only 7 crosses among 28 showed positive standard heterosis. The higher positive standard heterosis was shown by $(68.28 \%)(2 \times 5)$ and followed by $(2 \times 8)$ $(51.14 \%)$ combination. The remaining five combinations $(1 \times 2),(2 \times 6),(2 \times 7),(7 \times 8)$ and $(2 \times 4)$ showed less than $50 \%$ standard heterosis. Mishra and Yadav (1997) reported the best heterotic combination for seed yield CST-782 x N-32 giving (137.7\%) relative heterosis and (132.29\%) heterobeltiosis. Yadav et al. (2005) reported that two cross combinations, JTS-14 x HT-36 (87.50\%) and JIS-14x TC-328 (77.77\%) showed a higher degree of standard heterosis.

Positive relative heterosis was observed in all $\mathrm{F}_{2}$ s except the five crosses of $(1 \times 3),(3 \times 4),(3 \times 5),(3 \times 6)$ and $(6 \times 7)$ as shown in Figure 2. The maximum positive relative heterosis $(127.08 \%)$ was found in $(4 \times 5)$ combination. The best five crosses with maximum relative heterosis were $(4 \times 5),(7 \times 8),(1 \times 8),(1 \times 5)$ and $(2 \times 5)$ with the values of (127.08\%), (96.97\%), (90.65\%), (85.16\%) and (81.97\%) respectively. Only 19 among $28 \mathrm{~F}_{2}$ s showed positive heterobeltiosis while $9 \mathrm{~F}_{2} \mathrm{~s}$ exhibited negative heterobeltiosis. The combination $(4 \times 5)$ showed the highest and positive heterobeltiosis $(71.65 \%)$. The cross $(3 \times 4)$ had the highest negative heterobeltiosis value of $(-61.19 \%)$. The cross combinations of $(4 \times 5),(7 \times 8)$, and $(2 \times 6)$ were the best three crosses with the values of $(71.65 \%),(68.65 \%)$ and $(55.32 \%)$ respectively. When the $\mathrm{F}_{2}$ compared with the commercial variety (Hnanni 25/160), only 2 crosses among 28 showed positive standard heterosis. The positive standard heterosis was found in $(2 \times 6)(16.05 \%)$ and $(3 \times 8)$ $(2.70 \%)$.

\section{Analysis of combining ability variances in $F_{1}$ and $F_{2}$ progenies:-}

The mean squares from the combining ability analysis are shown in Table 2 . For $F_{1}$ progenies, the mean squares due to GCA and SCA were highly significant for plant height and capsules per plant. This indicated that both additive and non-additive types of gene actions were involved in the control of these characters. According to the report of Baker (1978), the relative importance of GCA and SCA should be assessed by estimating the two variance components and expressing them in the ratio, $2 \sigma_{\mathrm{GCA}}^{2} /\left(2 \sigma_{\mathrm{GCA}}^{2}+\sigma_{\mathrm{SCA}}^{2}\right)$. It was also described that the closer this ratio is to 1.0, the greater the reliability of GCA for determining progeny performance. For plant height, the ratio of GCA and SCA variance was 0.307 indicating the predominance of non-additive gene action. For capsules per plant, the ratio of GCA and SCA was 0.354 indicating the predominance of non-additive gene action. Similar findings 
were reported by Djima (1984). The mean squares due to general combining ability for days to maturity, primary branches, secondary branches, capsule length and yield per plant were highly significant, indicating that additive type of gene action was involved in the inheritance of these characters. Saravana and Nadarajan (2003) also observed that the GCA variances were greater than SCA variances for plant height and number of primary branches per plant indicating the predominance of additive gene actions for these traits.

For $\mathrm{F}_{2}$ progenies, the mean squares due to GCA and SCA were highly significant for days to primary branches, total branches and capsule length. This indicated that both additive and non-additive gene actions played a role in determining these characters in sesame. Similar results of $50 \%$ flowering and capsule length were obtained by Bakheit et al. (2005). The ratios of GCA and SCA variance were 0.566 for days to $50 \%$ flowering and 0.620 for primary braches indicating the predominance of additive gene action whereas the ratio of GCA and SCA variance was low in capsule length (0.41) indicating the predominance of non-additive gene action. The mean squares due to general combining ability were highly significant for days to maturity, plant height, secondary branches, capsules per plant, and yield per plant. This indicated that the additive gene actions were involved in these characters.

\section{General combining ability effects of $F_{1}$ progenies:-}

Estimates of the GCA effects of the parents and the SCA effects of the $\mathrm{F}_{1} \mathrm{~s}$ are presented in Table 3 and 4 . The parent 1 had highly significant positive GCA effect for total branches, capsules per plant and capsule length but highly significant negative GCA effect was found for primary branches. The parent 2 had highly significant positive GCA effect for days to maturity, plant height, primary branches, secondary branches, capsules per plant and yield per plant. The parent 3 had significant negative GCA effect for plant height. The parent 4 had highly negative significant GCA effect for primary branches, secondary branches and capsules per plant.

Highly significant negative GCA effect for days to maturity, plant height and capsule length was observed in parent 5. High significant positive GCA effect for primary branches was found in parent 6 . The parent 7 had negative significant GCA effect for secondary branches. Parent 8 had high positive significant GCA effect for days to and capsule length. The parent 2 showed high positive significant GCA for days to maturity, indicating that this line would be the best parent where late maturity is desired but highly negative significant GCA effect for this trait was found in parent 5 indicating that this line would be the best parent where early maturity is desired.

The parent 2 showed highly significant GCA for plant height this line would be good choice as parent where higher plant height is desired. If the numerous branches are desired, parent 2 would be the best line. Parent 1 and 8 would be the best parents for capsule length because they showed high positive significant GCA effect. Parent 2 showed highly positive significant GCA effect for yield per plant indicating that this line would be the best parent where high seed yield is desired.

\section{Specific combining ability effects of $F_{1}$ progenies:-}

Specific combining ability effects are also important in some combinations (Table 4). The positive significance of SCA effect was observed in $(1 \times 4)$ which would be late maturity. The combinations $(2 \times 5)$ and $(5 \times 7)$ had highly positive significant SCA effect for plant height. The cross of (1x5) was high positive significant in SCA effect for primary branches. The crosses of $(1 \times 5)$ and $(2 \times 8)$ were highly significant in SCA effects for secondary branches but (3x8) had highly negative significance. The cross of $(2 \times 8)$ was also significant in SCA effect for total branches. High significant SCA effect was found in (1x2) and (1x5) for capsules per plant. The cross $(7 \times 8)$ was significant in SCA effects for capsule length. The best positive specific combining ability for yield per plant was found in the combination $(2 \times 5)$ followed by $(2 \times 8)$ but negative significant SCA effect for this character was found in $(2 \times 3)$.

\section{General combining ability effects in $F_{2}$ progenies}

Estimates of GCA effects of the parents for ten characters of sesame are presented in Table 5. The parents 1 had highly positive significant GCA effect for plant height, capsules per plant and capsule length but for days to maturity, primary branches, secondary branches and, this parent showed negative significant GCA effect. The parent 2 had highly significant positive GCA effect for days to days to maturity, plant height, primary and secondary branches, capsules per plant and yield per plant. If the late maturity is desired, parent 2 would be the best. Parent 1 and 2 would be the best lines for higher plant height. Parent 4 showed highly negative significance for primary branches. High negative significance of GCA effects was observed in parent 5 for days to days to maturity, plant height, capsule length, and yield per plant. High negative significant GCA effect was observed in parent 7 for capsule length. Parent 8 had highly significant GCA effects for days to primary branches, total branches and capsule 
length. Parent 1 and 5 would be the best parents where early maturity is desired. If the late maturity is desired, parent 2 would be the best. Parent 1 and 2 would be the best lines for higher plant height. Parent 2 and 8 would be the best lines where the numerous branches are desired. The best two parents for capsules per plant were parent 1 and 2 , and parent 1 and 8 would be selected for capsule length. The best parent for higher seed yield was parent 2.

\section{Specific combining ability effects of $\mathbf{F}_{2}$ progenies:-}

Specific combining ability effects of $28 \mathrm{~F}_{2}$ progenies are presented in Table 6 . The crosses of $(1 \times 2),(3 \times 5)$ and $(3 \times 7)$ showed negative significant in SCA effect for days to maturity while the high positive significance was observed in $(2 \times 5)$ indicating this cross would be the best cross where the late maturity is desired.

High positive significance in SCA effect was found only in (1x2) for plant height but negative significant SCA effect was observed for this trait in $(3 \times 4)$. High positive significant SCA effect for primary branches was observed in $(1 \times 4),(1 \times 7),(2 \times 4)$ and $(3 \times 8)$ while the crosses of $(6 \times 7)$ and $(6 \times 8)$ showed negatively significance. For secondary branches the cross $(2 \times 3)$ showed negative significant SCA effect. The crosses of $(2 \times 5),(3 \times 8),(4 \times 6)$ and $(5 \times 6)$ showed positive significant SCA effect for capsule length while negative significance was observed in $(4 \times 8)$. The best combinations for seed yield was $(2 \times 6),(3 \times 8)$ and $(4 \times 5)$ indicating that these combinations would be the best lines where the high yield is desired in $\mathrm{F}_{2}$.

\section{Parents possess maximum mean values and GCA effects in different characters:-}

Selection of parents based on mean and GCA effects is described in Table 7. The parent 2 showed high mean and significant GCA effect for days to maturity, plant height, primary branches, secondary branches, and yield per plant. The parent 1 possessed high means and significant GCA effects for capsules per plant and capsule length. The parent 6 had high mean and significant GCA effect for primary branches, and parent 5 for only days to $50 \%$ flowering. The result indicated that parent 2 (Co-1) was identified as the best general combiner having high mean and significant GCA effect for more than half of the observed characters.

\section{Correlation coefficient between yield and yield component characters:-}

The correlation coefficients between yield and yield component characters are presented in Table 8. Yield per plant was significantly and positively correlated with days to maturity $\left(0.373^{*}\right)$, plant height $\left(0.714^{* *}\right)$, primary branches $(0.479 * *)$, secondary branches $\left(0.419^{* *}\right)$, and capsules per plant $\left(0.738^{* *}\right)$. Significant and negative correlation $(-$ $\left.0.474^{* *}\right)$ was observed between capsule length and capsules per plant. Capsules per plant was significantly and positively correlated with days to maturity $\left(0.314^{* *}\right)$, plant height $\left(0.596^{* *}\right)$, primary branches $\left(0.333^{*}\right)$, and secondary branches $\left(0.455^{* *}\right)$. Total branches was significantly and positively correlated with days to maturity $(0.542 * *)$, primary branches $(0.861 * *)$ and secondary branches $(0.857 * *)$. Secondary branches was positively and significantly correlated with days to maturity $\left(0.359^{* *}\right)$ and primary branches $(0.489 * *)$. Days to maturity was significantly correlated with plant height $(0.467 * *)$ and primary branches $(0.570 * *)$. Kambikambai et al. (1997) reported that yield was significantly and positively correlated with capsules per plant and 1000 seed weight. The significant positive association of plant height, branches per plant and capsules per plant with yield was found by Genesh and Sakila (1999). Kumar et al. (2002) and Yinghong and Yishou (2002) showed that capsules per plant and plant height were positively and significantly correctly with yield. Sarwar et al. (2005) showed a positive and significant correlation of plant height, branches per plant, capsules per plant and 1000 seed weight with yield.

\section{Conclusion:-}

Diallel analysis (Griffing's method II) was conducted to investigate correlation coefficient, heterosis, combining ability and genetic nature of eight sesame cultivars. From the study, it could be concluded that the best mean performance for yield per plant in first generation $\left(\mathrm{F}_{1}\right.$ hybrids $)$ was shown in $(2 \times 5)(\mathrm{Co}-1 \times$ India-7B), followed by $(2 \times 8)(\mathrm{Co}-1 \times$ Sinyadana 3$)$. The same results for standard heterosis were described as the same combinations $(2 \times 5)$ $(\mathrm{Co}-1 \times$ India-7B) and $(2 \times 8)(\mathrm{Co}-1 \times$ Sinyadana 3$)$.

The cross $(2 \times 5)$ possessed the highest relative heterosis $(229.68 \%)$, heterobeltiosis $(125.95 \%)$ and standard heterosis (68.82). The cross $(2 \times 8)$ showed the high relative heterosis $(165.67 \%)$, heterobeltiosis $(102.28 \%)$ and standard heterosis $(51.14 \%)$. In this experiment, the result manifested that parent 2 (Co-1) and parent 8 (Sinyadana 3 ) were the best two parents for yield. Not only the best good combiner, but also the best specific combining ability is also found in $(2 \times 5)(\mathrm{Co}-1 \times$ India-7B). The second best combination $(2 \times 8)(\mathrm{Co}-1 \times$ Sinyadana 3$)$ also possessed higher mean performance, higher heterosis and good in specific combining ability in yield. Therefore, the combinations of 
$(2 \times 5)($ Co-1 $\times$ India-7B) and $(2 \times 8)($ Co-1 $\times$ Sinyadana 3$)$ should be tested as hybrid varieties in sesame. However, multi-locations and multi-years and seasons should be needed to test the performance of yield.

In the second-generation $\left(\mathrm{F}_{2}\right.$ crosses $)$, the best yield performance was found in $(2 \times 6)(\mathrm{Co}-1 \times$ Yathaekyaw $)$, and the second was $(3 \times 8)$ (Sinyadana $8 \times$ Sinyadana 3$)$ and the third was $(1 \times 8)$ (Sinyadana $11 \times$ Sinyadana 3 ). The low inbreeding depression was found in the $(2 \times 6)\left(\mathrm{Co}-1 \times\right.$ Yathaekyaw) cross. The $\mathrm{F}_{2}$ generation might be used in production of sesame to save the cost of $F_{1}$ hybrid seeds. Among the $F_{2}$ generations, which showed significant $\mathrm{SCA}$ effect for yield per plant, $(2 \times 6)(\mathrm{Co}-1 \times$ Yathaekyaw) possessed higher yield performance. In correlation analysis study, yield per plant was significantly and positively correlated with days to maturity, plant height, primary branches, secondary branches, and capsules per plant. Therefore, these five characters were found to be the main yield contributing traits in sesame production.

There are environment effects in yield and other components and $\mathrm{G} \times \mathrm{E}$ interaction should be also considered. The right time of sowing in post-monsoon is important for normal growth and yield and yield components in sesame. The result of present study indicated that first week of October is a suitable time of sowing in sesame.

Generally, the GCA effect of parents was directly related to the $F_{1}$ performance of parents, i.e., the parents with high mean values showed high GCA effects. Therefore, the parents 2 (Co-1) would be utilized in the hybridization program for improving yield in sesame. In this study, days to maturity, primary branches, secondary branches, capsules length and yield per plant were highly significant. This result indicated that the additive gene effects were predominant for those characters and therefore, progeny selection will be effective to improve for these characters in $\mathrm{F}_{1}$ generation. For the later generation, days to maturity, plant height, secondary branches, capsules per plant, and yield per plant could be easily improved by selection. However, primary branches, total branches and capsule length could be difficult to improve by selection.

Table 1:- Analysis of variance for yield and yield components

\begin{tabular}{|c|c|c|c|c|c|c|c|c|}
\hline Source & d.f. & DM & PH & PB & SB & CPP & CL & YPP \\
\hline Environment (E) & 1 & $7154.500 * *$ & $18793.390 * *$ & 0.011 & 1.337 & $43364.850 * *$ & 8540.680 *** & 1247.110 ** \\
\hline \multicolumn{9}{|l|}{ Genotype (G) } \\
\hline Parents (P) & 7 & $43.642 * *$ & $537.570 * *$ & $8.152 * *$ & 2.409 & $107.390 *$ & $0.134 * *$ & $5.451 * *$ \\
\hline $\mathbf{F}_{1}$ & 27 & $20.982 * *$ & $226.160 * *$ & 3.481 ** & $4.807 * *$ & $342.135 * *$ & $0.040^{+}$ & $16.387 * *$ \\
\hline $\mathbf{F}_{2}$ & 27 & $2720.570 * *$ & $943.550 * *$ & $2.300 * *$ & $1.100 *$ & $308.450 *$ & $40.637^{+}$ & $10.689 * *$ \\
\hline Checks (C) & 3 & $20.729 * *$ & $84.277 * *$ & $3.538 * *$ & 0.360 & $86.245 * *$ & 0.109 & $9.827 * *$ \\
\hline $\mathbf{G} \times \mathbf{E}$ & 67 & $14.071 * *$ & $281.305^{* *}$ & $1.076^{* * *}$ & 1.076 & $471.721 * *$ & $163.163 * *$ & $8.497 * *$ \\
\hline Error & 67 & 2.770 & 72.188 & 0.488 & 0.939 & 49.036 & 13.144 & 2.551 \\
\hline
\end{tabular}

$+, *, * *=$ Significant at $10 \%, 5 \%$ and $1 \%$ probability levels, respectively

$\mathrm{DM}=$ Days to maturity, $\mathrm{PH}=\mathrm{Plant}$ height, $\mathrm{PB}=$ Primary branches, $\mathrm{SB}=$ Secondary branches,

$\mathrm{CPP}=$ Capsules per plant, $\mathrm{CL}=$ Capsule length, $\mathrm{YPP}=\mathrm{Yield}$ per plant

Table 2:- Mean squares from combining ability analysis of variance in $F_{1}$ and $F_{2}$ progenies

\begin{tabular}{|c|c|c|c|c|c|c|c|c|}
\hline \multicolumn{5}{|c|}{$\mathbf{F}_{1}$} & \multicolumn{4}{|c|}{$F_{2}$} \\
\hline \multirow[b]{2}{*}{ Cha. } & \multicolumn{3}{|c|}{ Mean Square } & \multirow{2}{*}{$\frac{2 \sigma_{G C A}^{2}}{\left(2 \sigma_{G C A}^{2}+\sigma_{S C A}^{2}\right)}$} & \multicolumn{3}{|c|}{ Mean Square } & \multirow{2}{*}{$\frac{2 \sigma_{G C A}^{2}}{\left(2 \sigma_{G C A}^{2}+\sigma_{S C A}^{2}\right)}$} \\
\hline & GCA & SCA & Error & & GCA & SCA & Error & \\
\hline DM & $27.746 * *$ & 8.642 & 5.458 & & $58.804 * *$ & 10.284 & 6.546 & - \\
\hline PH & $400.564 * *$ & $152.286^{* *}$ & 76.868 & 0.307 & $1087.013 * *$ & 72.033 & 173.763 & - \\
\hline PB & $8.327 * *$ & 0.663 & 0.625 & - & $5.665 * *$ & $0.754 * *$ & 0.301 & 0.620 \\
\hline SB & $4.994 * *$ & 1.386 & 0.815 & _- & $1.756 * *$ & 0.462 & 0.452 & - \\
\hline TB & $24.207 * *$ & 2.499 & 1.688 & & $12.492 * *$ & $1.763 * *$ & 0.639 & 0.598 \\
\hline $\mathbf{C P P}$ & $391.564 * *$ & $130.642 * *$ & 71.012 & 0.354 & $403.081 * *$ & 50.350 & 120.871 & - \\
\hline $\mathbf{C L}$ & $0.097 * *$ & 0.023 & 0.015 & _ & $0.101 * *$ & $0.028 * *$ & 0.014 & 0.410 \\
\hline YPP & $14.987 * *$ & 7.485 & 4.832 & & $8.047 * *$ & 4.414 & 1.387 & - \\
\hline
\end{tabular}

$* *=$ Significant at $1 \%$ probability level

$\mathrm{DM}=$ Days to maturity, $\mathrm{PH}=\mathrm{Plant}$ height, $\mathrm{PB}=$ Primary branches, $\mathrm{SB}=$ Secondary branches,

$\mathrm{CPP}=\mathrm{Capsules}$ per plant, $\mathrm{CL}=\mathrm{Capsule}$ length, $\mathrm{YPP}=$ Yield per plant 
Table 3:- General combining ability effects of parental genotypes in $F_{1}$ progenies

\begin{tabular}{|l|c|c|c|c|c|c|c|c|}
\hline \multirow{2}{*}{ Character } & \multicolumn{9}{|c|}{ Parental genotype } \\
\cline { 2 - 9 } & $\mathbf{P}_{\mathbf{1}}$ & $\mathbf{P}_{\mathbf{2}}$ & \multicolumn{1}{|c|}{$\mathbf{P}_{\mathbf{3}}$} & \multicolumn{1}{|c|}{$\mathbf{P}_{\mathbf{4}}$} & \multicolumn{1}{|c|}{$\mathbf{P}_{\mathbf{5}}$} & $\mathbf{P}_{\mathbf{6}}$ & $\mathbf{P}_{\mathbf{7}}$ & $\mathbf{P 8}$ \\
\hline DM & -0.250 & $2.350^{* *}$ & 0.550 & -0.550 & $-1.500^{* *}$ & -0.675 & -0.600 & 0.675 \\
\hline PH & 2.309 & $7.289^{* *}$ & $-3.761^{*}$ & 0.347 & $-7.528^{* *}$ & 2.013 & -2.141 & 1.471 \\
\hline PB & $-0.706^{* *}$ & $0.960^{* *}$ & 0.102 & $-1.114^{* *}$ & -0.040 & $0.343^{*}$ & 0.127 & 0.328 \\
\hline SB & -0.361 & $0.821^{* *}$ & 0.357 & $-0.568^{* *}$ & 0.165 & 0.248 & $-0.636^{* *}$ & -0.026 \\
\hline CPP & $4.13^{*}$ & $7.616^{* *}$ & -2.139 & $-6.510^{* *}$ & -1.190 & 1.931 & -0.806 & -3.035 \\
\hline CL & $0.088^{* *}$ & -0.021 & 0.019 & -0.014 & $-0.134^{* *}$ & 0.043 & -0.042 & $0.061^{*}$ \\
\hline YPP & -0.152 & $1.977^{* *}$ & -0.522 & -0.906 & -0.373 & 0.224 & -0.083 & -0.166 \\
\hline
\end{tabular}

$*, * *=$ Significant at $5 \%$ and $1 \%$ probabiliy levels, respectively

$\mathrm{DM}=$ Days to maturity, $\mathrm{PH}=\mathrm{Plant}$ height, $\mathrm{PB}=$ Primary branches, $\mathrm{SB}=$ Secondary branches,

$\mathrm{CPP}=$ Capsules per plant, $\mathrm{CL}=$ Capsule length, $\mathrm{YPP}=$ Yield per plant

Table 4:- Specific combining ability effects of $F_{1}$ progenies

\begin{tabular}{|c|c|c|c|c|c|c|c|}
\hline \multirow[t]{2}{*}{ Cross } & \multicolumn{7}{|c|}{ Character } \\
\hline & DM & PH & PB & SB & CPP & CL & YPP \\
\hline $1 \times 2$ & 1.372 & 9.242 & 0.698 & -0.544 & $12.166^{*}$ & 0.082 & 1.795 \\
\hline $1 \times 3$ & 1.422 & 4.211 & 0.302 & -0.746 & 0.591 & 0.117 & -0.396 \\
\hline $1 \times 4$ & $3.522 *$ & -3.567 & -0.318 & 0.010 & 0.877 & 0.040 & -0.977 \\
\hline $1 \times 5$ & 2.972 & 4.889 & $1.193^{*}$ & $2.022 * *$ & $13.222^{*}$ & -0.105 & 0.631 \\
\hline $1 \times 6$ & 0.147 & 5.517 & 0.476 & 0.108 & 0.521 & 0.048 & 0.883 \\
\hline $1 \times 7$ & -0.678 & 0.632 & -0.393 & 0.077 & 1.503 & -0.006 & -0.225 \\
\hline $1 \times 8$ & -0.703 & 0.974 & -0.510 & -0.532 & -4.848 & -0.095 & 0.338 \\
\hline $2 \times 3$ & -0.678 & -7.019 & -0.785 & 1.153 & -3.727 & -0.034 & $-3.020^{*}$ \\
\hline $2 \times 4$ & -1.078 & 10.038 & 0.186 & 0.248 & 5.728 & 0.024 & 0.349 \\
\hline $2 \times 5$ & 2.872 & $16.244 * *$ & 0.437 & 0.515 & 6.574 & 0.114 & $4.496 * *$ \\
\hline $2 \times 6$ & 2.047 & -1.128 & -0.271 & -0.568 & 10.538 & -0.038 & 1.529 \\
\hline $2 \times 7$ & -0.278 & -0.978 & 0.685 & -0.769 & 3.025 & 0.007 & 1.026 \\
\hline $2 \times 8$ & 1.197 & 2.579 & 0.155 & $2.098 * *$ & 7.334 & 0.054 & $2.979^{*}$ \\
\hline $3 \times 4$ & -1.578 & 3.168 & 0.044 & $\begin{array}{l}-0.038 \\
\end{array}$ & 1.149 & 0.019 & 0.638 \\
\hline $3 \times 5$ & -0.578 & 0.463 & -0.120 & 0.974 & -6.711 & 0.019 & 0.200 \\
\hline $3 \times 6$ & -1.653 & 2.672 & -0.422 & 0.895 & 7.198 & 0.037 & 1.383 \\
\hline $3 \times 7$ & -2.478 & 0.991 & -0.201 & -0.061 & -1.975 & -0.028 & 0.170 \\
\hline $3 \times 8$ & -1.753 & -2.536 & -0.318 & $-1.250 *$ & -2.411 & 0.079 & -0.082 \\
\hline $4 \times 5$ & 1.272 & 4.940 & 0.186 & -0.016 & -2.470 & 0.117 & -0.281 \\
\hline $4 \times 6$ & -0.053 & 2.979 & 0.553 & -0.599 & 2.506 & 0.125 & 1.097 \\
\hline $4 \times 7$ & 0.622 & 6.883 & 0.019 & 0.285 & -0.354 & 0.110 & 0.039 \\
\hline $4 \times 8$ & -1.403 & -0.729 & -0.852 & -0.325 & 1.210 & -0.128 & -0.418 \\
\hline $5 \times 6$ & -2.603 & -3.396 & -0.861 & -0.662 & 3.799 & 0.035 & -0.116 \\
\hline $5 \times 7$ & 0.178 & $12.509 *$ & -0.555 & 0.052 & 6.241 & 0.040 & 1.086 \\
\hline $5 \times 8$ & -2.203 & -0.769 & -0.506 & -1.058 & 1.055 & 0.057 & 0.354 \\
\hline $6 \times 7$ & -1.003 & -3.868 & -0.192 & -0.532 & -5.335 & 0.008 & -0.586 \\
\hline $6 \times 8$ & -0.028 & 5.270 & 0.021 & 0.529 & 3.519 & 0.030 & 0.227 \\
\hline $7 \times 8$ & 0.647 & 6.259 & 0.577 & 0.243 & 10.171 & $0.160^{*}$ & 2.139 \\
\hline Grand of $5 \%$ & 3.042 & 11.415 & 1.029 & 1.175 & 10.972 & 0.159 & 2.862 \\
\hline Grand of $1 \%$ & 4.081 & 15.315 & 1.381 & 1.577 & 14.721 & 0.214 & 3.840 \\
\hline
\end{tabular}

$*, * *$ significant at $1 \%$ and $5 \%$ levels, respectively

$\mathrm{DM}=$ Days to maturity, $\mathrm{PH}=\mathrm{Plant}$ height, $\mathrm{PB}=$ Primary branches, $\mathrm{SB}=$ Secondary branches,

$\mathrm{CPP}=$ Capsules per plant, $\mathrm{CL}=\mathrm{Capsule}$ length, $\mathrm{YPP}=$ Yield per plant 
Table 5:- General combining ability effects of parental genotypes in $\mathrm{F}_{2}$ progenies

\begin{tabular}{|l|c|c|c|c|c|c|c|c|}
\hline \multirow{2}{*}{ Cha. } & \multicolumn{9}{|c|}{ Parental genotype } \\
\cline { 2 - 9 } & $\mathbf{P}_{\mathbf{1}}$ & $\mathbf{P}_{\mathbf{2}}$ & $\mathbf{P}_{\mathbf{3}}$ & $\mathbf{P}_{\mathbf{4}}$ & $\mathbf{P}_{\mathbf{5}}$ & $\mathbf{P}_{\mathbf{6}}$ & $\mathbf{P}_{\mathbf{7}}$ & $\mathbf{P}_{\mathbf{8}}$ \\
\hline DM & $-3.287^{* *}$ & $2.588^{* *}$ & 0.113 & 0.338 & $-1.337^{* *}$ & 0.238 & 0.363 & 0.988 \\
\hline PH & $9.260^{* *}$ & $11.838^{* *}$ & -5.344 & -1.149 & $-10.604^{* *}$ & -0.178 & -3.412 & 0.178 \\
\hline PB & $-0.826^{* *}$ & $0.825^{* *}$ & 0.055 & $-0.662^{* *}$ & -0.045 & 0.111 & 0.142 & $0.393^{* *}$ \\
\hline SB & $-0.390^{* *}$ & $0.489^{* *}$ & 0.069 & -0.175 & -0.285 & 0.138 & -0.120 & 0.272 \\
\hline CPP & $6.481^{* *}$ & $7.885^{* *}$ & -1.719 & -1.853 & -3.390 & -3.139 & -1.943 & -2.321 \\
\hline CL & $0.099^{* *}$ & -0.007 & -0.006 & -0.009 & $-0.130^{* *}$ & 0.039 & $-0.052^{*}$ & $0.067 * *$ \\
\hline YPP & 0.475 & $1.239^{* *}$ & -0.036 & -0.112 & $-0.879^{*}$ & -0.503 & -0.073 & -0.112 \\
\hline
\end{tabular}

$*, * *=$ Significant at $5 \%$ and $1 \%$ probability levels, respectively

$\mathrm{DM}=$ Days to maturity, $\mathrm{PH}=\mathrm{Plant}$ height, $\mathrm{PB}=$ Primary branches, $\mathrm{SB}=$ Secondary branches,

$\mathrm{CPP}=$ Capsules per plant, $\mathrm{CL}=\mathrm{Capsule}$ length, $\mathrm{YPP}=$ Yield per plant

Table 6:- Specific combining ability effects of $\mathrm{F}_{2}$ progenies

\begin{tabular}{|c|c|c|c|c|c|c|c|}
\hline \multirow[t]{2}{*}{ Cross } & \multicolumn{7}{|c|}{ Character } \\
\hline & DM & PH & PB & SB & CPP & CL & YPP \\
\hline $1 \times 2$ & $-3.647 *$ & $30.243 * *$ & 0.127 & -0.381 & 0.275 & 0.038 & -0.778 \\
\hline $1 \times 3$ & -0.672 & 1.174 & -1.284 & -0.132 & 1.359 & -0.069 & -0.598 \\
\hline $1 \times 4$ & -1.147 & -2.211 & $0.833^{*}$ & 0.112 & 9.343 & -0.020 & 0.163 \\
\hline $1 \times 5$ & 1.778 & 4.769 & 0.351 & 0.222 & 11.610 & 0.100 & 1.545 \\
\hline $1 \times 6$ & 0.203 & 1.648 & 0.530 & -0.200 & 6.504 & -0.083 & 0.364 \\
\hline $1 \times 7$ & 1.078 & 7.408 & $0.780 *$ & 0.057 & -0.017 & -0.053 & 0.149 \\
\hline $1 \times 8$ & -1.047 & -2.832 & -0.021 & -0.335 & -1.389 & 0.104 & 1.713 \\
\hline $2 \times 3$ & -2.047 & 1.431 & -0.479 & $-1.010^{*}$ & 2.885 & -0.052 & 0.158 \\
\hline $2 \times 4$ & 2.728 & 6.101 & $0.903 *$ & 0.254 & 10.539 & 0.011 & 0.114 \\
\hline $2 \times 5$ & $3.653 *$ & 12.986 & 0.621 & -0.106 & 11.076 & $0.157 *$ & 1.351 \\
\hline $2 \times 6$ & 2.328 & 0.070 & -0.015 & 0.256 & 8.830 & -0.132 & $2.585^{*}$ \\
\hline $2 \times 7$ & 2.453 & -5.020 & 0.255 & 0.479 & 3.029 & $0 . .99$ & 0.390 \\
\hline $2 \times 8$ & 1.578 & -8.140 & -0.516 & 0.037 & 0.337 & 0.030 & 0.314 \\
\hline $3 \times 4$ & 1.453 & $-18.132 *$ & 0.228 & -0347 & -12.357 & 0.140 & -1.396 \\
\hline $3 \times 5$ & $-3.372 *$ & -2.847 & 0.041 & -0.237 & -4.490 & -0.085 & -1.089 \\
\hline $3 \times 6$ & 0.053 & -10.863 & -0.465 & -0.659 & -13.851 & -0.148 & -2.230 \\
\hline $3 \times 7$ & $-3.572 *$ & 0.161 & 0.484 & 0.718 & 12.851 & 0.127 & 1.460 \\
\hline $3 \times 8$ & -0.197 & 15.191 & $0.953 *$ & 0.506 & 12.851 & $0.194 *$ & $2.524 *$ \\
\hline $4 \times 5$ & -0.097 & 16.518 & -0.407 & 0.007 & 5.529 & 0.104 & $2.686^{*}$ \\
\hline $4 \times 6$ & 0.828 & 7.972 & 0.202 & -0.265 & -1.307 & $0.175^{*}$ & 0.710 \\
\hline $4 \times 7$ & 0.453 & 7.501 & 0.271 & -0.158 & 2.432 & -0.004 & 0.460 \\
\hline $4 \times 8$ & 1.328 & -4.524 & -0.080 & -0.600 & 2.340 & $-0.193 *$ & -1.115 \\
\hline $5 \times 6$ & 0.508 & 2.862 & -0.015 & -0.305 & -1.520 & $0.206^{* *}$ & 0.007 \\
\hline $5 \times 7$ & 0.878 & -6.019 & -0.416 & -0.048 & -6.701 & -0.094 & -1.138 \\
\hline $5 \times 8$ & -0.497 & -10.104 & -0.097 & -0.440 & -8.333 & -0.097 & -1.078 \\
\hline $6 \times 7$ & 0.303 & -8.665 & $-0.752^{*}$ & -0.470 & -6.847 & 0.068 & -1.474 \\
\hline $6 \times 8$ & -3.072 & -5.605 & $-0.783^{*}$ & -0.562 & -0.098 & 0.029 & -0.454 \\
\hline $7 \times 8$ & -0.447 & 12.475 & -0.298 & -0.155 & 7.436 & -0.000 & 1.841 \\
\hline Grand of $5 \%$ & 3.331 & 17.162 & 0.714 & 0.875 & 14.314 & 0.153 & 2.323 \\
\hline Grand of $1 \%$ & 4.470 & 23.027 & 0.958 & 1.174 & 19.205 & 0.205 & 3.117 \\
\hline
\end{tabular}

$*, * *=$ Significant at $5 \%$ and $1 \%$ probability levels, respectively

$\mathrm{DM}=$ Days to maturity, $\mathrm{PH}=\mathrm{Plant}$ height, $\mathrm{PB}=$ Primary branches, $\mathrm{SB}=$ Secondary branches,

$\mathrm{CPP}=$ Capsules per plant, $\mathrm{CL}=\mathrm{Capsule}$ length, $\mathrm{YPP}=$ Yield per plant 
Table 7:- Parents possess maximum mean values and GCA effects in different characters

\begin{tabular}{|l|l|l|l|}
\hline \multicolumn{1}{|c|}{ Character } & \multicolumn{1}{c|}{ Mean } & \multicolumn{1}{c|}{ GCA effect } & \multicolumn{1}{c|}{ Mean and GCA effect } \\
\hline Days to maturity (days) & $\mathrm{P}_{2}, \mathrm{P}_{3}, \mathrm{P}_{8}$ & $\mathrm{P}_{2}$ & $\mathrm{P}_{2}$ \\
\hline Plant height (cm) & $\mathrm{P}_{2}, \mathrm{P}_{6}, \mathrm{P}_{8}$ & $\mathrm{P}_{2}$ & $\mathrm{P}_{2}$ \\
\hline Primary branches (no.) & $\mathrm{P}_{2}, \mathrm{P}_{6}, \mathrm{P}_{8}$ & $\mathrm{P}_{2}, \mathrm{P}_{6}$ & $\mathrm{P}_{2}, \mathrm{P}_{6}$ \\
\hline Secondary branches (no.) & $\mathrm{P}_{2}, \mathrm{P}_{6}$ & $\mathrm{P}_{2}$ & $\mathrm{P}_{2}$ \\
\hline Capsules per plant (no.) & $\mathrm{P}_{1}, \mathrm{P}_{3}, \mathrm{P}_{6}$ & $\mathrm{P}_{1}, \mathrm{P}_{2}$ & $\mathrm{P}_{1}$ \\
\hline Capsule length (cm) & $\mathrm{P}_{1}, \mathrm{P}_{6}$ & $\mathrm{P}_{1}$ & $\mathrm{P}_{1}$ \\
\hline Yield per plant (g) & $\mathrm{P}_{1}, \mathrm{P}_{2}, \mathrm{P}_{3}$ & $\mathrm{P}_{2}$ & $\mathrm{P}_{2}$ \\
\hline
\end{tabular}

$\mathrm{P}_{1}=$ Sinyadana $11, \mathrm{P}_{2}=$ Co- $1, \mathrm{P}_{3}=$ Sinyadana $8, \mathrm{P}_{4}=$ Yamato,

$\mathrm{P}_{5}=$ India- 7B, $\mathrm{P}_{6}=$ Yethaekyaw, $\mathrm{P}_{7}=$ VTS- 2009, $\mathrm{P}_{8}=$ Sinyadana 3

Table 8:- Correlation coefficients $(r)$ among the characters in 40 sesame genotypes $\left(\mathrm{P}+\mathrm{F}_{1} \mathrm{~s}+\mathrm{Checks}\right)$

\begin{tabular}{|l|c|c|c|c|c|c|}
\hline \multicolumn{1}{|c|}{ Cha. } & $\begin{array}{c}\text { Days to } \\
\text { maturity }\end{array}$ & $\begin{array}{c}\text { Plant } \\
\text { height }\end{array}$ & $\begin{array}{c}\text { Primary } \\
\text { branches }\end{array}$ & $\begin{array}{c}\text { Secondary } \\
\text { branches }\end{array}$ & $\begin{array}{c}\text { Capsules } \\
\text { per plant }\end{array}$ & $\begin{array}{c}\text { Capsule } \\
\text { length }\end{array}$ \\
\hline $\begin{array}{l}\text { Plant } \\
\text { height }\end{array}$ & $0.467 * *$ & & & \\
\hline $\begin{array}{l}\text { Primary } \\
\text { branches }\end{array}$ & $0.570^{* *}$ & 0.272 & & & \\
\hline $\begin{array}{l}\text { Secondary } \\
\text { branches }\end{array}$ & $0.395^{* *}$ & 0.274 & $0.489 * *$ & & & \\
\hline $\begin{array}{l}\text { Capsules per } \\
\text { plant }\end{array}$ & $0.314^{*}$ & $0.596^{* *}$ & $0.333^{*}$ & $0.455^{* *}$ & & \\
\hline $\begin{array}{l}\text { Capsule } \\
\text { length }\end{array}$ & 0.162 & -0.056 & 0.091 & -0.227 & $-0.474^{* *}$ & \\
\hline $\begin{array}{l}\text { Yield per } \\
\text { plant }\end{array}$ & $0.373^{*}$ & $0.714^{* *}$ & $0.479 * *$ & $0.419 * *$ & $0.738^{* *}$ & -0.142 \\
\hline
\end{tabular}

$*, * *=$ significant at $1 \%$ and $5 \%$ probability levels, respectively

Appendix 1:- List of eight parental lines of sesame varieties and their Original Sources

\begin{tabular}{|c|l|l|l|}
\hline \multicolumn{1}{|c|}{ Variety } & \multicolumn{1}{c|}{ Original source } & \multicolumn{1}{c|}{ Remark } \\
\hline $\mathbf{1}$ & Sinyadana 11 & China x Korea & Breeding line \\
\hline $\mathbf{2}$ & CO-1 & India & Breeding line \\
\hline $\mathbf{3}$ & Sinyadana 8 & India & Breeding line \\
\hline $\mathbf{4}$ & Yamato & Japan & Breeding line \\
\hline $\mathbf{5}$ & India-7 B & India & Breeding line \\
\hline $\mathbf{6}$ & Yathaekyaw & Myanmar & Local variety \\
\hline $\mathbf{7}$ & VTS -2009 & India & Breeding line \\
\hline $\mathbf{8}$ & Sinyadana 3 & Myanmar & Released cultivar \\
\hline Check 1 & Sinyadana 3 & Myanmar & Released cultivar \\
\hline Check 2 & Sinyadana 4 & China & Released cultivar \\
\hline Check 3 & Hnanni 25/160 & Myanmar & Local cultivar \\
\hline Check 4 & Magway 7/9 & Myanmar & Local cultivar \\
\hline
\end{tabular}




\section{References:-}

1. Allard, R. W. 1956. Estimation of prepotency from lima bean diallel crosses data. Agron. J. 48:537-543.

2. Baker, R. J. 1978. Issues in diallel analysis. Crop Sci. 18:533-536.

3. Baker,R. J. 1988. Testes for crosses genotype x environment interactions. Can. J. Plant Sci. 68:405-410.

4. Bakheit, B. R., M. Z. EI-Hiffny, A. A. EI-Shiemy and G. B. Abd EI-Azziz. 2005. Application of two different mating designs to determine gene action in sesame: triple test cross and diallel technique. Sesame and Safflower Newsl. 20:38-41.

5. Djima, A. 1984. Genetic conditioning of characters linked to yield in sesame. Oleagineus. 39:217-225.

6. Ganesh, S. K. and M. Sakila. 1999. Generation mean analysis in sesame crosses. Sesame and Safflower Newsl. 17:45-49.

7. Giriraj, K. and S. Vijayakumar. 1974. Path coefficient analysis of yield attributes in mungbean. Indian J. Genet. 34(1):27-30.

8. Griffing, B. 1956. Concept of general and specific combining ability in related to diallel crossing system. Austral. J. Bio. Sci. 9:463-493.

9. Kambikambai, M., P. Hussain and R. Susanna. 1997. Path analysis in segregating population. Madras Agri. J. 86:158-159.

10. Kumar, S. P., P. Sundararajan and P. Thangavelu. 2002. Variability studies in the second generation of intervaterial crosses in sesame. Sesame and Safflower Newsl. 17:36-40.

11. Mulkey, J. R. Jr., H. J. Drawe and R. E. Jr. Elledge. 1987. Planting date effects on plant growth and development in sesame. Agron. J. 79:701-703.

12. Ramalingam, R. S. S., R. S. Rangaswami, S. A. Narayanan. 1994. Hybrid sesame group discussion. Directorate of Oilseeds Research, Hyderabad, $14^{\text {th }}$ June, 1994. pp. 23-26.

13. Saravana, S. and N. Nadarajan. 2003. Combining ability studies in sesame. Sesame and Safflower Newsl. 18:1-6

14. Sarwar, G., M. A. Haq and M. Saleem Mughal. 2005. Genetic parameters and correlation study in diverse type of sesame germplasm. Sesame and safflower Newsl. 20:31-34.

15. Shim, K. B., C. W. Kang, D. W. Kim and Y. A. Chae. 2006. Effect of sowing dates on flowering and maturity of sesame. Korean J. Crop Sci. 51(2):113-117.

16. UTz, H. F. 1997. A computer program for statistical analysis of plant breeding experiments. Version $2 \mathrm{~N}$. Institute of Plant Breeding, Seed Science and Population Genetics, University of Hohenheim.

17. Walton, P. D. 1971. Heterosis in spring wheat. Crop Sci. 11:422-424.

18. Yadav, L. N. and A. K. Mishra. 1991. Line x tester analysis of combining ability in sesame. Sesame and safflower Newsl. 5:68-72.

19. Yingzhong, Z. and W. Yishou. 2002. Genotypic correlations and path coefficient analysis in sesame. Sesame and safflower Newsl. 17:10-12. 